\title{
THE
}

2014

\section{Coffee Stirrers and Drinking Straws as Disposable Spatulas}

\author{
Cinzia Lobuono \\ University of Rhode Island \\ Morgan A. Turano \\ University of Rhode Island \\ Louis J. Kirschenbaum \\ University of Rhode Island, Ikirsch@uri.edu
}

Follow this and additional works at: https://digitalcommons.uri.edu/chm_facpubs

The University of Rhode Island Faculty have made this article openly available.

Please let us know how Open Access to this research benefits you.

This is a pre-publication author manuscript of the final, published article.

Terms of Use

This article is made available under the terms and conditions applicable towards Open Access

Policy Articles, as set forth in our Terms of Use.

\section{Citation/Publisher Attribution}

Lobuono, C., Turano, M. A , \& Kirschenbaum, L. J. (2014). Coffee stirrers and drinking straws as disposable spatulas. Journal of Chemical Education, 92(1), 197-198. doi: 10.1021/ed5006322

Available at: http://dx.doi.org/10.1021/ed5006322

This Article is brought to you for free and open access by the Chemistry at DigitalCommons@URI. It has been accepted for inclusion in Chemistry Faculty Publications by an authorized administrator of DigitalCommons@URI. For more information, please contact digitalcommons-group@uri.edu. 


\title{
Coffee Stirrers and Drinking Straws as Disposable Spatulas
}

Cinzia Lobuono; Morgan A. Turano, M.S.; Louis J. Kirschenbaum*, Ph.D.

Department of Chemistry, University of Rhode Island, 51 Lower College Road, Kingston, R.I. 02881, United States

\begin{abstract}
While metal spatulas are damaged through everyday use and become discolored and corroded by chemical exposure, drinking straws are inexpensive and disposable, reducing the risk of cross contamination during laboratory experiments. Drinking straws are also useful because they come in a variety of sizes; narrow sample containers such as NMR and EPR tubes can easily be filled using small diameter coffee stirrers, while bulk material can be transferred using larger drinking straws.

Several types of drinking straws and coffee stirrers were cut at various angles and the amount of material picked up in a single scoop was massed thirty times. Standard deviations of the thirty measurements per straw indicate that approximately the same amount of material will be scooped each time by the same operator.
\end{abstract}




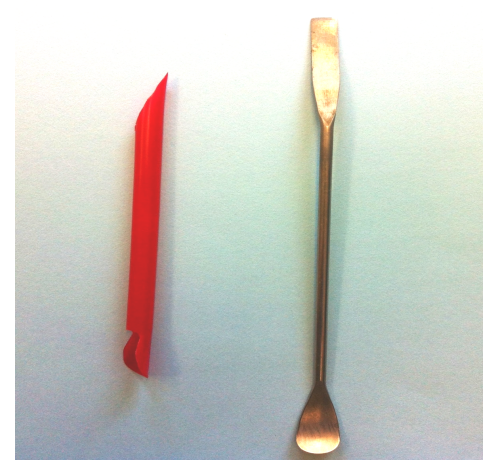

\section{KEYWORDS}

General Public, Laboratory Instruction, Hands-On Learning/Manipulatives, Laboratory Equipment/Apparatus

One of the major problems in chemistry teaching laboratories is the cost of labware. ${ }^{1,2,3}$ Use of household and improvised items in place of expensive laboratory counterparts has therefore been in practice. ${ }^{1,2,4}$ We have found that using straws cut at an acute angle in place of spatulas in teaching laboratories decreases the cost and increases the effectiveness of scooping devices, as well as solves the difficulties caused by using damaged metal spatulas.

Drinking straws and coffee stirrers are readily available and have been suggested as replacements for traditional spatulas in amateur and grade school laboratories. ${ }^{3,4,5}$ Since straws are inexpensive and disposable they can also been used in research as well as teaching laboratories of all levels. ${ }^{1,2,6,7}$ The cost of a box of 500 drinking straws is 
approximately $\$ 6.00$ and a box of 1000 coffee stirrers is approximately $\$ 5.00,{ }^{8}$ while a typical pack of only 12 metal spatulas is around $\$ 50 .{ }^{9}$

Metal spatulas are damaged through everyday use, becoming discolored by certain chemicals such as solid metal phthalocyanines and corroded by chemical exposure; inexpensive straws can be rinsed or simply thrown away after a single use. Since they are so easily replaceable, the risk of cross contamination is minimized.

The curved sides of the straw prevent the spills which students often experience while using flat spatulas. This is particularly important when weighing in an enclosed analytical balance. The use of plastic straws also decreases the risks associated with scooping shock sensitive materials. In our laboratories, small diameter coffee stirrers have proven particularly useful for filling narrow sample tubes such as EPR tubes, while larger diameter drinking straws are more useful for transferring bulk material.

To test the effectiveness of using straws as spatulas, several types of drinking straws and coffee stirrers were cut at acute angles (Fig. 1), and the amount of sodium chloride transferred in a single transfer was measured; this measurement was repeated thirty times with each straw by a single operator. The scoop end of smoothie spoon straws 9 and 11 were also used for measurements. Smoothie spoon straws cost approximately $\$ 10$ for 400 straws, ${ }^{8}$ and can hold several grams of material in a single transfer. 


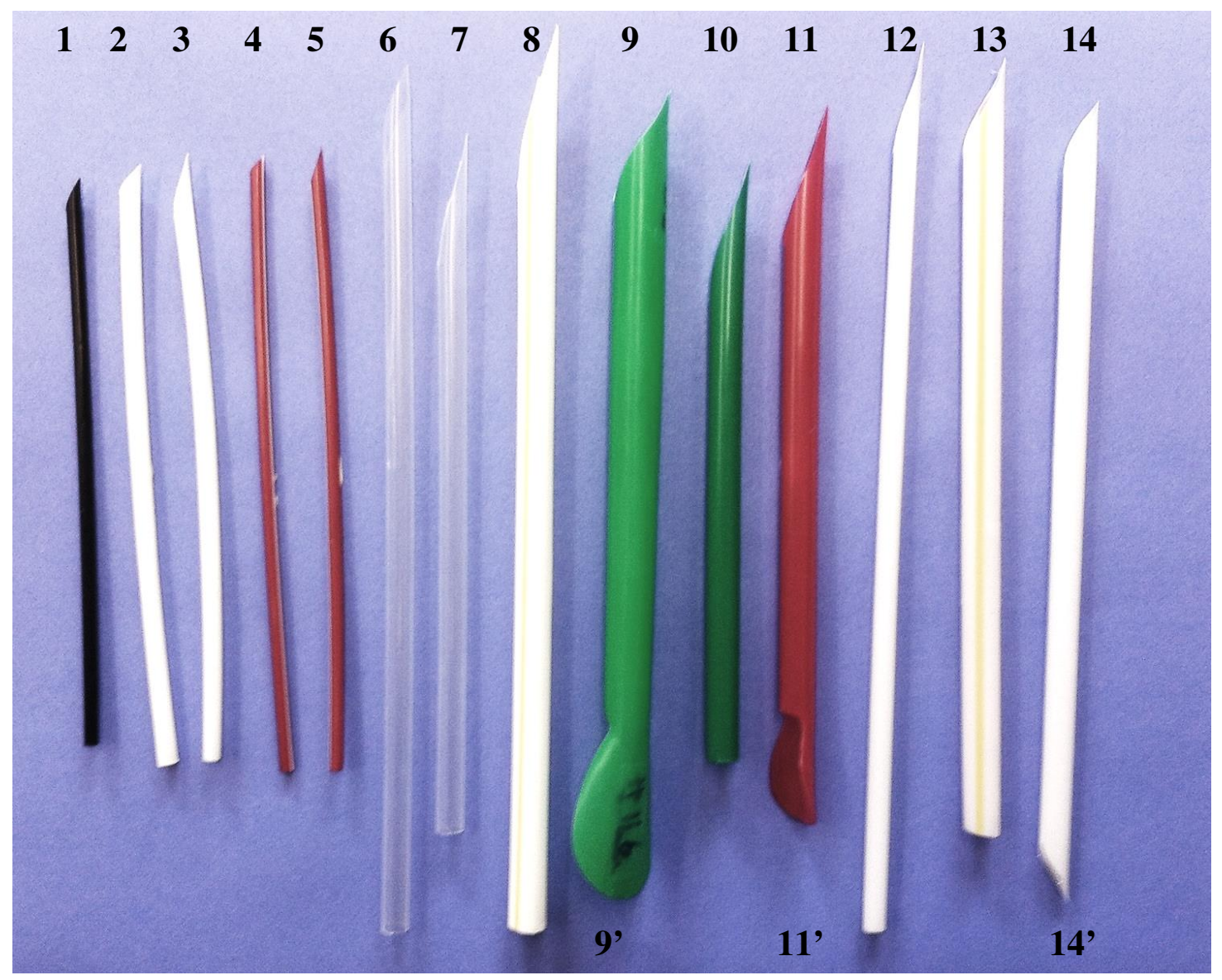

Figure 1: Fourteen straws cut for use as disposable spatulas.

\section{FINDINGS}

The average mass picked up by each straw are compiled in Table 1, along with information about the type, diameter, and the angle of the cut straw. The consistency of the measurement was verified by cutting each end of a single straw to the same angle and using each end to perform the analysis (straws 14 and 14'). As expected, a straw with the same diameter and cut angle produced similar average masses over their respective thirty measurements; Straw 14 has an average mass of 0.4556g, while Straw 14' has an average mass of $0.4208 \mathrm{~g}$. This confirms good reproducibility for a single operator. 
Table 1: Straw measurements and amount of material per scoop.

\begin{tabular}{|c|c|c|c|c|c|c|c|}
\hline & \multicolumn{3}{|c|}{\begin{tabular}{l|l} 
Diameter $(\mathrm{cm})$ & Angle \\
\end{tabular}} & \multirow{2}{*}{$\begin{array}{c}\text { Avg } \\
0.0432\end{array}$} & \multirow{2}{*}{$\begin{array}{c}\text { StDev } \\
0.0067\end{array}$} & \multirow{2}{*}{\begin{tabular}{|l|l}
$\%$ \\
16
\end{tabular}} \\
\hline \multirow{5}{*}{ 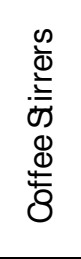 } & $\begin{array}{l}\frac{\mathrm{d}}{0} \\
\frac{1}{0}\end{array}$ & 1 & 0.2 & 28.1 & & & \\
\hline & $\stackrel{0}{=}$ & 2 & 0.4 & 39.7 & 0.0955 & 0.0077 & 8 \\
\hline & $\sum_{3}^{5}$ & 3 & 0.4 & 19.6 & 0.0754 & 0.0104 & 14 \\
\hline & $\bar{\delta}$ & 4 & 0.3 & 38.4 & 0.0182 & 0.0032 & 18 \\
\hline & \& & 5 & 0.3 & 18.7 & 0.0359 & 0.0032 & 9 \\
\hline \multirow{10}{*}{ 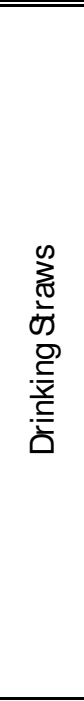 } & $\bar{d}$ & 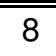 & 0.7 & 15.1 & 1.0613 & 0.1345 & 13 \\
\hline & के & 13 & 0.7 & 28.3 & 0.7802 & 0.0637 & 8 \\
\hline & & 6 & 0.5 & 21.1 & 0.3284 & 0.0447 & 14 \\
\hline & ॠ & 7 & 0.5 & 14.3 & 0.3945 & 0.0333 & 8 \\
\hline & O̊ & 14 & 0.5 & 28.9 & 0.4556 & 0.0382 & 8 \\
\hline & & $14^{\prime}$ & 0.5 & 29.0 & 0.4208 & 0.0306 & 7 \\
\hline & 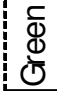 & 9 & 1.1 & 25.5 & 2.2522 & 0.2733 & 12 \\
\hline & 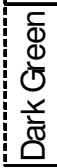 & 10 & 0.7 & 19.1 & 0.9082 & 0.0578 & 6 \\
\hline & 8 & 11 & 0.7 & 17.6 & 0.8715 & 0.0546 & 6 \\
\hline & $\frac{0}{\stackrel{5}{*}}$ & 12 & 0.5 & 12.1 & 0.4365 & 0.0287 & 7 \\
\hline \multirow{2}{*}{$\begin{array}{l}\frac{\pi}{D} \\
\frac{\pi}{0} \\
\frac{\pi}{\alpha} \\
\end{array}$} & $\begin{array}{ll}\bar{d} \\
\delta\end{array}$ & $9^{\prime}$ & 1.1 & $x$ & 5.2739 & 0.4396 & 8 \\
\hline & 8 & $11^{\prime}$ & 0.7 & $x$ & 1.6380 & 0.0986 & 6 \\
\hline
\end{tabular}

Figure 2 shows that there is a gradual increase in capacity with increased diameter. Standard deviations of the thirty measurements per straw indicate that approximately the same amount of material will be scooped each time by the same operator. 


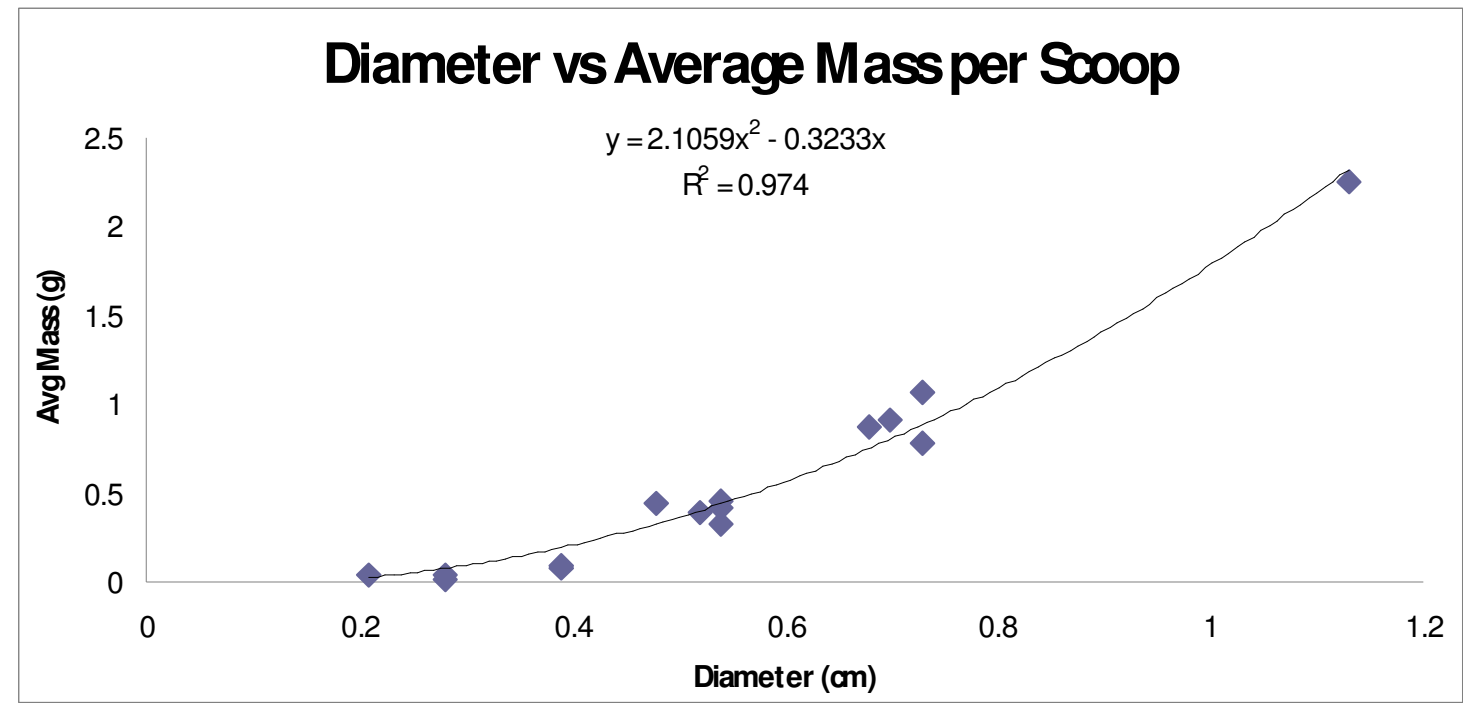

Figure 2: Diameter of straw verses average mass per scoop. The trend line assumes a y-intercept of zero.

There is, however, variation in masses when the operator intentionally changed the angle of the straw's insertion into the salt, and when different operators use the same straw. Further, the mass transferred is also dependant on the density, crystal size, and adhesion properties of the material being transferred. For example, the mass of boric acid transferred with Straw 1 and Straw 2 were $0.0282 \mathrm{~g}$ and $0.0535 \mathrm{~g}$, or $65 \%$ and $55 \%$ of the amount of sodium chloride transferred with the same straws.

\section{CONCLUSIONS}

The coffee stirrers, straws, and scoops included in this study have a capacity between $0.018 \mathrm{~g}$ to over five grams. With practice it is possible for an individual to estimate how much of a particular material he or she expects to pick up in a single scoop using a straw of a given diameter. This would allow an operator to transfer approximately the amount of solid material needed prior to massing on an analytical balance. Since this 
transfer can be performed away from the balance, there would be a reduction in spillage on, and damage to, delicate equipment.

\author{
AUTHOR INFORMATION \\ Corresponding Author \\ *Email: kirschenbaum@chm.uri.edu
}

\title{
REFERENCES
}

1. DeWitt, C.B. Household Comes to the Lab. J. Chem. Educ. 1936, 577-80.

2. Bishop, R.D. Microscale on a Budget. J. Chem. Educ. 1994, 71 (10), A252-3.

3. Science Teachers Association of Ontario. http://stao.ca/resources/safetyinfo/article10.php (accessed July 2014).

4. Chemistry with Cabbage. http://www.chemistrywithcabbage.co.uk/scienceset.php (accessed May 2014).

5. San Diego Science Olympiad. http://www.sandiegoso.org/divb2013/d.b.crime.html (accessed May 2014).

6. Roberts, A. Bio 311: Plant Structure and Development Lab Manual, Fall 2012. http://www.uri.edu/cels/bio/plant_anatomy/ (accessed May 2014).

7. Thompson, S. Chemtrek: Small-Scale Experiments for General Chemistry; Prentice-Hall: NJ, 1990; pp 73-74.

8. Amazon. http://www.amazon.com (accessed May 2014).

9. Fisher Scientific. http://www.fishersci.com (accessed July 2014). 